\title{
Paleolimnological investigations of anthropogenic environmental change in Lake Tanganyika: VI. Geochemical indicators
}

\author{
C.M. O'Reilly ${ }^{1, *}$, D.L. Dettman ${ }^{2}$ and A.S. Cohen ${ }^{2}$ \\ ${ }^{1}$ Environmental Science Program, Vassar College, Poughkeepsie, NY 12604, USA; ${ }^{2}$ Department of \\ Geosciences, University of Arizona, Tucson, AZ 85721, USA; *Author for correspondence (e-mail: \\ caoreilly@vassar.edu)
}

Received 10 July 2004; accepted in revised form 15 January 2005

Key words: Carbon isotopes, Deforestation, Lake Tanganyika, Late Holocene, Nitrogen isotopes, Soil erosion

\begin{abstract}
Geochemical signals of bulk sedimentary organic matter from three cores from Lake Tanganyika provided information about both internal processes and terrestrial inputs to the lake. Indications of land use change were detected in the geochemical records of the watersheds, and the timing of these changes was consistent with historical records of population demographics. While $\mathrm{C}: \mathrm{N}$ ratios suggested that the distance from shore might be important in influencing the relative amount of allochthonous vs. autochthonous material, all cores were dominated by autochthonous organic matter. In general, nitrogen isotopes were more positive at disturbed sites, indicating inputs of enriched soil nitrate that was subsequently taken up by phytoplankton. In contrast, carbon isotopes did not reflect land use patterns, and a post-1950s decline in carbon isotope ratios found in all cores may indicate a lake-wide decrease in productivity. These interpretations were consistent with pollen and climate records.
\end{abstract}

\section{Introduction}

Lake Tanganyika's catchment is characterized by a range of disturbance levels both in terms of current land use patterns and the history of human influence. Disturbed areas have high human population densities and population growth rates are as high as $2.2 \%$ (CIA 2004). Deforestation rates are as high as $100 \%$ in the north and $40-60 \%$ in the central areas (Cohen et al. 1993), and cleared land becomes grassland or is used for cultivation of bananas, maize, cassava, and other crops. Vegetation in less undisturbed watersheds consists primarily of semi-deciduous woodland and canopy forests with areas of open grassland at higher elevations. Soil erosion rates in highly disturbed areas can be as high as 28-100 metric tons per ha per year (Bizimana and Duchafour 1991). Deforestation is associated with erosion, which increases both sediment and nutrient load in the lake. These changes in land use affect terrestrial inputs and can have severe consequences for the lake (Cohen et al. 1993; Alin et al. 2002). This study aimed to identify the timing of land use change using geochemical signals in the cores.

Biogeochemical signals in lake sediments have been used to detect both natural and anthropogenic changes in watersheds. Carbon:nitrogen $(\mathrm{C}: \mathrm{N})$ ratios of the organic matter distinguish clearly between terrestrial and aquatic material, 
with terrestrial plant material having a higher proportion of carbon required for woody support tissues, whereas molar $\mathrm{C}: \mathrm{N}$ ratios of aquatic algae are generally less than 15 (Meyers 1994). Carbon isotope ratios of bulk organic matter are useful for studying vegetation changes because they can differentiate between C3 plants (phytoplankton, trees, temperate grasses; -25 to $-28 \%{ }_{0}^{13} \mathrm{C}$ ) and $\mathrm{C} 4$ plants (tropical grasses; -10 to $-14 \% \delta^{13} \mathrm{C}$ ) (Smith and Epstein 1971; Peterson and Fry 1987). These vegetation shifts can occur due to either natural disturbance (fires, climate change) or anthropogenic disturbance (deforestation). Nitrogen isotopes can be useful indicators of human impacts, because nitrogen (usually in the form of nitrate) from soil and human and animal wastes tends to be more enriched in ${ }^{15} \mathrm{~N}$ compared to either terrestrial or aquatic vegetation (Kendall 1998; Kao and Liu 2000).

We used stable carbon and nitrogen isotope ratios and $\mathrm{C}: \mathrm{N}$ ratios in three cores collected in the Lake Tanganyika Biodiversity Project's Special Study on Sedimentation as indicators of land use patterns in the Lake Tanganyika watershed. High human population growth along the northeast lakeshore has led to rapid deforestation and conversion to open grassland and agriculture. This might be expected to shift the landscape from one dominated by $\mathrm{C} 3$ trees to one dominated by $\mathrm{C} 4$ grasses, which should be clearly evident as a shift towards more positive carbon isotope ratios. $\mathrm{C}: \mathrm{N}$ ratios should allow us to distinguish between autochthonous and allochthonous material, with ratios much higher than 10 in disturbed watersheds indicating a proportionally greater input of terrestrial plant material. Furthermore, we expected to see differences in the $\delta^{15} \mathrm{~N}$ values of the organic matter, with disturbed watersheds having more positive values indicating inputs of soil nitrogen (subsequently taken up by phytoplankton), in the range of $4-10 \%$ (Kendall 1998; Kao and Liu 2000). We expected that geochemical records in the cores would be consistent with historic land use patterns. Prior to extensive human settlement in the 1800s we might expect geochemical signatures of all cores to be similar, with a subsequent change to more positive $\delta^{13} \mathrm{C}$ and $\delta^{15} \mathrm{~N}$ values and higher $\mathrm{C}: \mathrm{N}$ ratios in disturbed watersheds commensurate with historical records of population increases.

\section{Methods}

Geochemical analyses were done on three cores collected along the northeast shoreline (For more detailed information see Tables 1 and 2, and Figures 4 and 5 in Cohen et al. 2005). The cores were collected using a Hedrick-Marrs Multicorer as part of the UNDP/GEF Lake Tanganyika Biodiversity Project and dated using ${ }^{210} \mathrm{~Pb}$ and ${ }^{14} \mathrm{C}$ (McKee et al. 2005). They were from generally smaller watersheds within the Lake Tanganyika catchment and cover a range of disturbance regimes, from protected forest (Kahama - LT-98$58 \mathrm{M}$ ), disturbed (Mwamgongo - LT-98-37M), to highly disturbed (Karonge/Kirasa - LT-98-82M). The protected watershed contains less than $10 \%$ open grassland and is located within Gombe Stream National Park. The Mwamgongo and Karonge/Kirasa sites are both nearly 100\% deforested, although the latter has a much more dispersed population and has probably had a longer history of human impact. Detailed descriptions of the watersheds are available in Cohen et al. (2005).

We analyzed bulk organic matter for carbon and nitrogen isotopes approximately every $3 \mathrm{~cm}$, with the exception of the top 3-6 cm, for which there was not enough material remaining after earlier work on these cores. Large time periods between data points were due to low sedimentation rates between the sampled core slices.

We did not correct the carbon isotope ratios for the recent depletion of atmospheric $\delta^{13} \mathrm{C}$ (the Suess effect) for several reasons. First, the lake does not appear to be in equilibrium with atmospheric $\mathrm{CO}_{2}$. Even though there has been an increase in atmospheric $\mathrm{pCO}_{2}$, dissolved inorganic carbon (DIC) concentrations have not changed since the 1970s (Sarvala et al. 1999) and represent supersaturation. The DIC concentrations indicate that the lake is a net source of $\mathrm{CO}_{2}$ to the atmosphere, which is consistent with other work that shows most lakes, including tropical African lakes, are net heterotrophic (Cole et al. 1994). This evidence suggests that we do not need to correct for the Suess effect.

All samples were acidified with $10 \% \mathrm{HCl}$ for at least $24 \mathrm{~h}$ and rinsed three times by decanting after centrifugation. Bulk sedimentary organic matter was analyzed at the University of Waterloo Environmental Isotope Lab on an Isochron 
Continuous Flow Stable Isotope Mass Spectrometer (Micromass) coupled to a Carla Erba Elemental Analyzer (CHNS-O EA1108) with standard error of $0.2 \%$ for carbon and $0.3 \%$ for nitrogen. Samples with low $\% \mathrm{~N}$ were run additionally at the University of Arizona on a Finnigan Delta-plus Continuous Flow Mass Spectrometer coupled to a Costech Elemental Analyzer with a standard error of $0.1 \%$ for carbon and $0.15 \%$ for nitrogen. The isotope ratios are expressed in delta notation with respect to deviation from standard reference material (Pee Dee belemnite carbon and atmospheric nitrogen).

\section{Results}

Nitrogen isotope ratios were different between the disturbed and undisturbed watersheds (Figure 1).

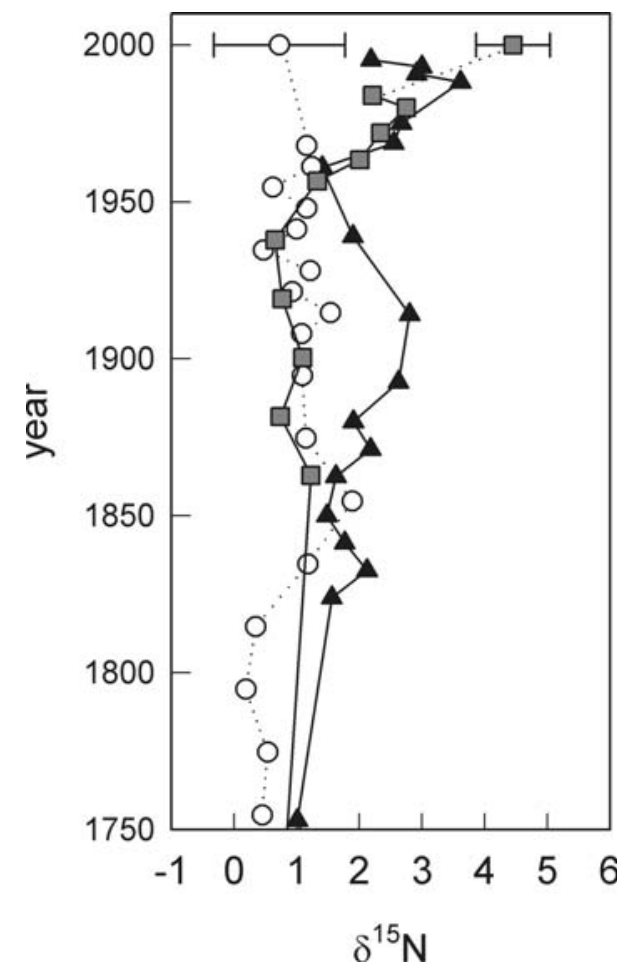

Figure 1. Nitrogen isotope ratios. Open circles represent the undisturbed watershed (Kahama), grey squares represent the disturbed watershed (Mwamgongo), and closed triangles represent the highly disturbed watershed (Karonge). Core $\delta^{15} \mathrm{~N}$ ratios were compared to surface sediments from the undisturbed and disturbed watershed. The surface sediments are shown as mean \pm standard deviation in year 2000 , connected to the uppermost core samples by a dotted line.
In the undisturbed watershed (Kahama) $\delta^{15} \mathrm{~N}$ ratios averaged $0.9 \pm 0.4 \%$ (standard deviation) and changes over time were minimal. In contrast, $\delta^{15} \mathrm{~N}$ ratios at the disturbed watershed (Mwamgongo) became more positive after 1962. The highly disturbed watershed (Karonge/Kirasa) had much more positive $\delta^{15} \mathrm{~N}$ values throughout most of the core, beginning in the early 1800 s.

Carbon isotopes ranged from $-21.98 \%$ to $-20.78 \%$ (Figure 2). Between ca. 1870 and 1940, the cores from the disturbed watersheds had more negative $\delta^{13} \mathrm{C}$ ratios than the undisturbed watershed. After 1950, all cores showed a general trend towards more negative $\delta^{13} \mathrm{C}$ values since 1950.

Molar C:N ratios differed among cores, but remained relatively constant downcore (Figure 3ac). The undisturbed watershed had the highest average C:N ratios $(15.6 \pm 0.3)$, then the disturbed watershed $(14.2 \pm 0.2)$. In contrast to what we expected, the very highly disturbed watershed had the lowest $\mathrm{C}: \mathrm{N}$ ratios $(11.5 \pm 0.1)$.

In general, there were no relationships between $\delta^{13} \mathrm{C}$ and $\% \mathrm{C}$ or $\mathrm{C}: \mathrm{N}$ ratios in any of the cores

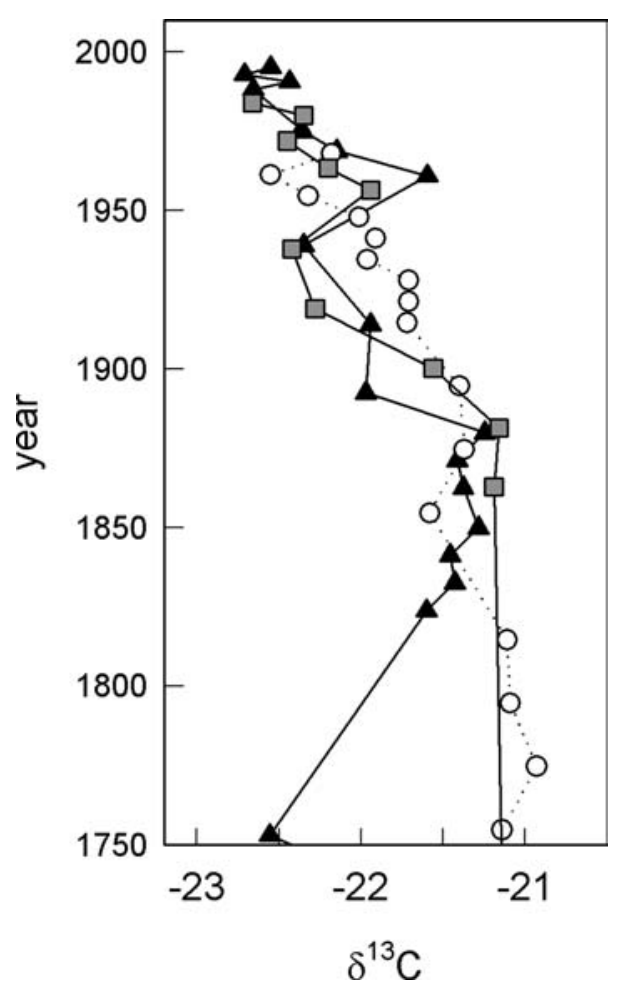

Figure 2. Carbon isotope ratios. Symbols are as in Figure 1. 


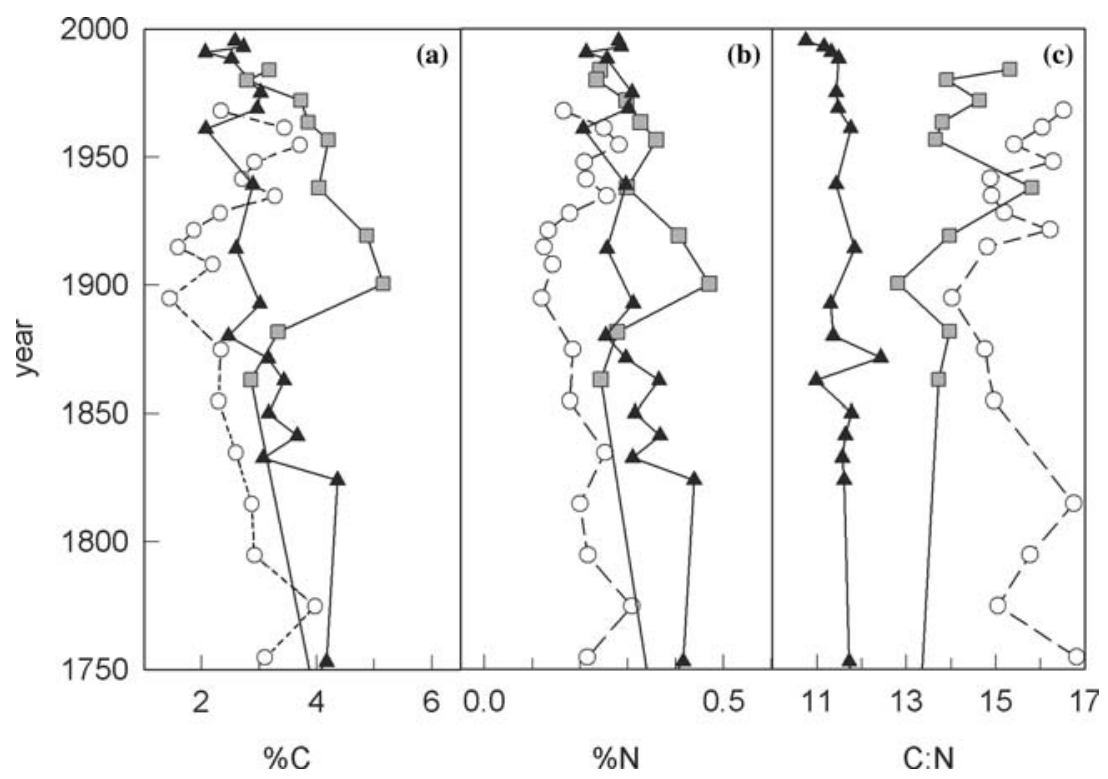

Figure 3. $\% \mathrm{C}, \% \mathrm{~N}$, and molar C:N ratios. Symbols are as in Figure 1. (a) $\% \mathrm{C}$. (b) $\% \mathrm{~N}$. The absence of any downcore trends indicates minimal diagenetic change of sedimentary organic matter. (c) C:N ratios. The low C:N values in each core are consistent with dominance by autochthonous material.

(Figure 4a,b). In addition, there were no trends in $\mathrm{C}: \mathrm{N} . \% \mathrm{C}$ and $\% \mathrm{~N}$ were highly correlated in each core (Kahama $r^{2}=0.89$; Mwamgongo $r^{2}=0.98$; Karonge $\left.r^{2}=0.99\right)$.

\section{Discussion}

There may be some concerns when comparing absolute geochemical signals among cores. Distance from shore may have been a factor influencing the relative amount of allochthonous and autochthonous organic matter in the sediments. Sediments further from the shoreline may have less allochthonous particulate organic material because these particles are typically larger than algae and would have settled out of the water column at shallower depths where the river enters the lake. The undisturbed and disturbed cores were both taken about the same distance from the river mouth, whereas the highly disturbed core was twice as far from the shoreline (Cohen et al. 2005). The C:N ratios could be reflecting this difference, since very low $\mathrm{C}: \mathrm{N}$ ratios in the highly disturbed core indicate predominantly autochthonous material, while the other nearer cores have slightly higher $\mathrm{C}: \mathrm{N}$ ratios that are consistent with the

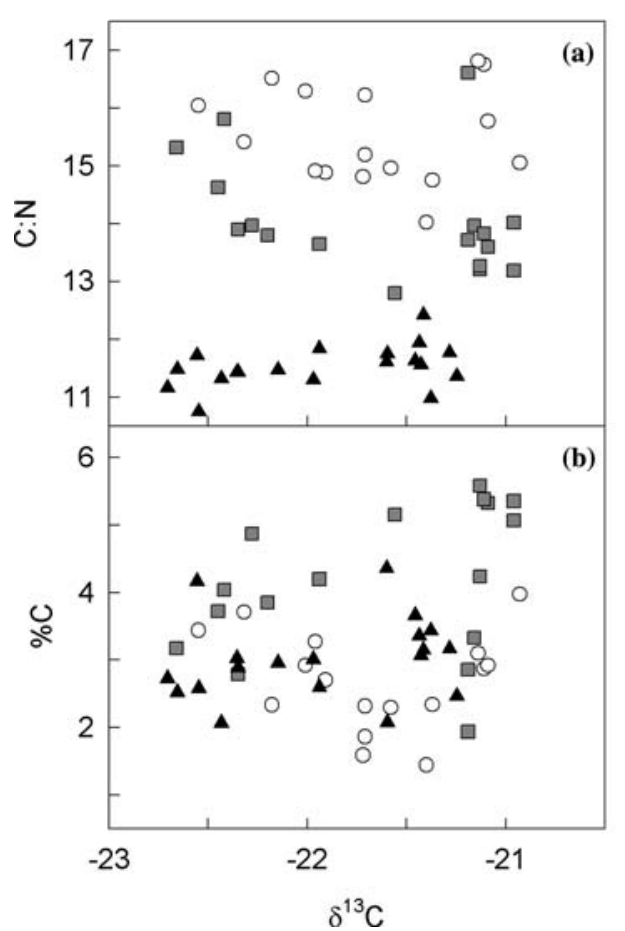

Figure 4. Geochemical relationships in the cores. Symbols are as in Figure 1. (a) $\delta^{13} \mathrm{C}$ and molar $\mathrm{C}: \mathrm{N}$ ratios. (b) $\delta^{13} \mathrm{C}$ and $\% \mathrm{C}$. The absence of correlations between data for $\delta^{13} \mathrm{C}$ and either $\% \mathrm{C}$ or C:N suggests that there has not been significant diagenesis. 
possibility of minor terrestrial inputs. This complicates the validity of comparisons among cores, particularly between the highly disturbed core and the other cores. However, this restriction primarily applies to allochthonous particulate inputs that would be transported by river water into the lake.

Nevertheless, the organic matter chemistry within a core does reflect the land use patterns. The C:N ratios at the disturbed site shift to slightly higher average values after the early 1900s $(13.9 \pm 0.4$ vs. $14.4 \pm 0.3)$, consistent with increasing human population density. In contrast, there is no change at the undisturbed site $(15.7 \pm 0.5$ vs. $15.5 \pm 0.4)$. There are also no trends in the highly disturbed core, other than a shift towards lower $\mathrm{C}: \mathrm{N}$ ratios at the very top of the core $(11.4 \pm 0.1 \mathrm{vs}$. $11.6 \pm 0.1)$. This pattern could be because of initial degradation just prior to preservation (Meyers and Ishiwatari 1993). The higher C:N ratios of the undisturbed core compared to the disturbed core (water depth $95 \mathrm{~m}$ ) could exist for a similar reason, because the shallower core depth $(76 \mathrm{~m})$ at the undisturbed site may allow for oxic conditions at the sediment interface.

However, diagenesis did not appear to be a major problem in the overall geochemical record of these sediments. Whereas diagenetic alteration of isotopic composition may occur in sediments with high percent organic matter $(\mathrm{OM})$ of $>20$ $28 \%$ by loss-on-ignition (Meyers and Ishiwatari 1993), these core sediments and cores all had much lower OM concentrations (Figure 3b; PalaciosFest et al. 2005). Other evidence against diagenesis was that (a) there were no downcore trends in $\% \mathrm{~N}, \% \mathrm{C}$, or $\mathrm{C}: \mathrm{N}$ ratios, (b) $\% \mathrm{C}$ and $\% \mathrm{~N}$ are highly correlated in each core, and (c) there is no significant relationship between $\% \mathrm{C}$ and $\delta^{13} \mathrm{C}$ or between $\% \mathrm{~N}$ and $\delta^{15} \mathrm{~N}$ in any of the cores (Figure 4; Talbot and Johannessen 1992).

Nitrogen isotopes in the cores differed depending upon current land use patterns. At the undisturbed site, the $\delta^{15} \mathrm{~N}$ values throughout the cores were around $1 \%$. This value is similar to those found in phytoplankton in the lake (O'Reilly et al. 2003b), providing further support that the organic matter is predominantly autochthonous material. Ideally, more cores from other undisturbed locations would be needed to provide a stronger record of autochthonous processes, but at least initially, this core served as a baseline for nitrogen isotope ratios in other locations. Nitrogen isotopes of surface sediments from the same disturbed watershed (Mwamgongo) and a different undisturbed watershed in Gombe Stream National Park were consistent with the differences found between these two cores (Figure 1). Compared to the undisturbed site, both disturbed sites trended towards more positive nitrogen isotope ratios, particularly in recent history.

The timing of the nitrogen isotope changes in the cores coincided with periods of increase in human population densities in the watersheds. In the undisturbed watershed, there were no changes in $\delta^{15} \mathrm{~N}$ downcore. However, at the disturbed watershed Mwamgongo, the shift towards more positive $\delta^{15} \mathrm{~N}$ ratios occurred after 1940. In 1943, the population density in this watershed increased because Gombe Stream Reserve was established and the inhabitants were relocated to Mwamgongo village. Additional increases in village population size occurred in 1972 with the government 'villagization' program (Cohen et al. 2005). The highly disturbed watershed had more positive nitrogen isotopes throughout the record, consistent with the longer history of larger population size and more intense land use (Cohen et al. 2005). This relationship between changes in human population density and nitrogen isotope ratios suggests that nitrogen isotopes may be a good indicator of human impacts.

Carbon isotope ratios in the cores did not correlate with land use patterns. The disturbed watersheds had a greater proportion of grassland, and we expected this to be associated with more positive $\delta^{13} \mathrm{C}$ ratios due to inputs of $\mathrm{C} 4$ plant material. In contrast, all watersheds show a general trend towards more negative $\delta^{13} \mathrm{C}$ (Figure 3). Within an aquatic environment, a trend towards more negative $\delta^{13} \mathrm{C}$ values of bulk sedimentary organic matter often indicates a decrease in primary productivity (Meyers and Ishiwatari 1993). Lake Tanganyika is permanently stratified, and periodic upwelling of deeper waters provides an important source of nutrients (Hecky 1991). Warming of Lake Tanganyika, associated with global warming over this same time period, may have increased thermal stability of the lake, reducing the frequency and/or magnitude of upwelling events and causing a decrease in primary productivity (O'Reilly et al. 2003a). Terrestrial inputs of organic material did not influence this chemical shift because there were no changes in 
$\mathrm{C}: \mathrm{N}$ ratios during this time; the organic matter remains dominated by algal material. In the case of carbon isotopes, autochthonous processes dominate the sedimentary record and may have overwhelmed any disturbance signal.

There are a few instances where the carbon isotope data vary from this long term trend towards more negative ratios. The most notable of these variations is around 1950-1960, where there is a peak with more positive $\delta^{13} \mathrm{C}$ in the disturbed watersheds. This time period correlates with greater charcoal flux in all cores and a substantial increase in sedimentation rates only in the disturbed watersheds (Palacios-Fest et al. 2005). This suggests that there may have been widespread fires around this time. The loss of vegetation may have increased erosion, and sediment losses would be greater in the disturbed watersheds, which would have been dominated by easily burned vegetation such as grasses. Burning in the forested watershed would be associated with lower sediment losses because burning removes primarily undergrowth and the presence of trees (even as burned stumps) would curtail soil erosion because of more extensive root masses. Precipitation was above average in the early 1960s (lake level was 4-8 m higher), which would also have contributed to greaterthan-normal losses for exposed soils. Subsequently, the input of soil nutrients to the shoreline could have increased algal productivity, leading to more positive $\delta^{13} \mathrm{C}$ ratios in the sediments.

Other records also indicate changes consistent with shifting vegetation patterns in the disturbed watersheds and increased soil erosion at this time. The disturbed watershed shows increases in woodland, dry forest, and herbaceous plant pollen in the 1940s, coincident with decreases in some evergreen and montane forest pollen (Msaky et al. 2005). The highly disturbed watershed shows a similar pattern, but with the shift beginning in the early 1900s. In contrast, the undisturbed watershed shows no change in herbaceous pollen, an increase in some evergreen and montane forest species and a decrease in some woodland and dry forest species in the late 1950s (Msaky et al. 2005). Overall, the pollen record is consistent with a shift towards deforestation and more grasses in the disturbed sites. In addition, the nitrogen isotope record at the disturbed sites shows a shift towards more positive nitrogen isotope ratios indicating soil nitrogen inputs at this time.

\section{Conclusion}

Overall, nitrogen isotopes were the most useful geochemical indicator of anthropogenic impact on Lake Tanganyika. C:N ratios provided important insights into the source of sedimentary organic matter, and indicated a relative decrease in allochthonous material further offshore. While this may affect comparisons among cores, the sedimentary record within a core could still be used to provide information about the timing of different events in the watershed. While there appears to be a relationship between human population density and soil nitrate losses, climatic factors were probably also important in controlling soil erosion. While higher resolution sampling of the cores could be helpful, geochemical analyzes of more cores would provide information to develop baseline nitrogen isotope signals for this lake. The use of these geochemical indicators has useful application to understanding the complex interactions between climatic and anthropogenic impacts in the Lake Tanganyika watershed.

\section{Acknowledgements}

We thank the Global Environmental Facilities' Lake Tanganyika Biodiversity Project for financial support of this research. We especially thank Drs. A. Menz and G. Patterson for their extensive support in all aspects of this project, and the crew of the $R / V$ Tanganyika Explorer, especially Captain Kimosa and R. Makere for their help with core collection. We thank R. E. Hecky and the University of Waterloo Environmental Isotope Lab for analytical assistance, the Tanzanian Council for Scientific Research (COSTECH), the Tanzanian Fisheries Research Institute (TAFIRI), and the University of Burundi, for their support of this research program. This is contribution \#169 of the International Decade of East African Lakes (IDEAL).

\section{References}

Alin S.R., O'Reilly C.M., Cohen A.S., Dettman D.L., PalaciosFest M.R. and McKee B.A. 2002. Recent land-use change and biodiversity history at Gombe Stream National Park, Tanzania. Geology 30: 1143-1146. 
Bizimana M. and Duchafour H. 1991. A drainage basin management study: The case of the Ntihangwa River Basin. In: Cohen A.S. (ed.), Report of the First International Conference on Conservation and Biodiversity of Lake Tanganyika. Biodiversity Support Program, Washington D.C, pp. 43-45.

Central Intelligence Agency 2004. The World Factbook. http:// www.cia.gov/cia/publications/factbook/index.html.

Cohen A.S., Bills R., Cocquyt C.Z. and Caljon A.G. 1993. The impact of sediment pollution on biodiversity in Lake Tanganyika. Conserv. Biol. 7: 667-677.

Cohen A.S., Palacios-Fest M.R., McGill J., Swarzwenski P.W., Verschuren D., Sinyinza R., Songori T., Kakagozo B., Syampila M., O'Reilly C.M. and Alin S.R. 2005. Investigations of anthropogenic environmental change in Lake Tanganyika: I. An introduction to the project. J. Paleolimnol. 34: 1-18.

Cole J.J., Caraco N.F., Kling G.W. and Kratz T.K. 1994. Carbon dioxide supersaturation in the surface water of lakes. Science 265: 1568-1570.

Hecky R.E. 1991. The nutrient regime. In: Coulter G.W. (ed), Lake Tanganyika and its Life. Oxford University Press, New York, pp. 76-89.

Kao S.J. and Liu K.K. 2000. Stable carbon and nitrogen isotope systematics in a human-disturbed watershed (LanyangHsi) in Taiwan and the estimation of biogenic particulate organic carbon and nitrogen fluxes. Global Biogeochem. Cy. 14: 189-198.

Kendall C. 1998. Tracing nitrogen sources and cycles in catchments. In: Kendall C. and McDonnell J.J. (eds), Isotope Tracers in Catchment Hydrology. Elsevier, New York, pp. 519-576.

McKee B.A., Cohen A.S., Dettman D.L., Palacios-Fest M.R., Alin S.A. and Ntungumburangye G. 2005. Paleolimnological investigations of anthropogenic environmental change in Lake Tanganyika: II. Geochronologies and mass sedimentation rates based on ${ }^{14} \mathrm{C}$ and ${ }^{210} \mathrm{~Pb}$ data. J. Paleolimnol. 34: 19-29.

Meyers P.A. 1994. Preservation of elemental and isotopic source identification of sedimentary organic matter. Chem. Geol. 114: 289-302.
Meyers P.A. and Ishiwatari R. 1993. Lacustrine organic geochemistry - an overview of indicators of organic matter sources and diagenesis in lake sediments. Org. Geochem. 20: 867-900.

Msaky E.S., Livingstone D. and Davis O.K. 2005. Paleolimnological investigations of anthropogenic environmental change in Lake Tanganyika: V: Palynological evidence for deforestation and increased erosion. J. Paleolimnol. 34: 73-83.

O'Reilly C.M., Alin S.R., Plisnier P.-D., Cohen A.S. and McKee B.A. 2003a. Climate warming decreases aquatic ecosystem productivity of Lake Tanganyika, Africa. Nature 424: 766-768

O'Reilly C.M., Verburg P., Hecky R.E., Plisnier P.-D. and Cohen A.S. 2003b. Food web dynamics in stable isotope ecology: Time integration of different trophic levels. In: Seuront L. and Strutton P. (eds), Handbook of Scaling Methods in Aquatic Ecology: Measurement, Analysis, Simulation. CRC Press, Boca Raton, Florida, pp. 125-134.

Palacios-Fest M.R., Cohen A S., Lezzar K., Nahimana L. and Tanner B.M. 2005. Paleolimnological investigations of anthropogenic environmental change in Lake Tanganyika: III: Physical stratigraphy and charcoal analysis. J. Paleolimnol. 34: 31-49.

Peterson B.J. and Fry B. 1987. Stable isotopes in ecosystem studies. Ann. Rev. Ecol. Syst. 18: 293-320.

Sarvala J., Salonen K., Jarvinen M., Aro E., Huttula T., Kotilainen P., Kurki H., Langenberg V., Mannini P., Peltonen A., Plisnier P.-D., Vuorinen I., Molsa H. and Lindqvist O.V. 1999. Trophic structure of Lake Tanganyika: carbon flows in the pelagic food web. Hydrobiologia 407: 149-173.

Smith B.N. and Epstein S. 1971. Two categories of ${ }^{13} \mathrm{C} /{ }^{12} \mathrm{C}$ ratios for higher plants. Plant Physiol. 47: 380-384.

Talbot M.R. and Johannessen T. 1992. A high resolution palaeoclimatic record for the last 27,500 years in tropical West Africa from the carbon and nitrogen isotope composition of lacustrine organic matter. Earth Plant. Sci. Lett. 110: $23-37$ 